\title{
Socializace sportem
}

\section{Socialization By Sport}

\author{
Libor Flemr, Zdeněk Valjent
}

Fakulta tělesné výchovy a sportu Univerzity Karlovy v Praze

Ústav tělesné výchovy a sportu, České vysoké učení technické v Praze

\begin{abstract}
Abstrakt
$V$ dnešní době tzv. informační společnosti, kdy ubývá přirozeného sociálního kontaktu mezi lidmi, se opět výrazně dostává do popredé socializační potenciál sportovních aktivit. Nejen celosvětovou rozšiřreností, popularitou, aktivním provozováním a mediální pozorností lze o sportu hovořit jako o společenském fenoménu dnešní doby. Tyto aspekty sportu př̀náší možnost ovlivňovat dění ve společnosti a naopak.

Ve výzkumech zabývajicích se socializací sportu je relativnè dlouhá tradice diferencovat mezi socializací do sportu, socializací během či prostřednictvím sportu a dále socializací přimo ve sportu. Ovšem zejména $v$ souvislosti s dnešní velmi pestrou sportovní nabídkou, která zahrnuje mnoho různorodých pohybových aktivit z mnoha hledisek, lze jen těžko generalizovat zjištěné závěry na více sportovních odvětví (individuální, kolektivní) a predevším výkonnostních úrovní (rekreační, výkonnostní, vrcholová). Navíc di̊vody pro sportování mohou být značně individuální, proto je di̊ležité zejména dètem a mládeži nabízet pestrou škálu sportovního vyžití ve všech výkonnostních úrovních a míre organizovanosti.
\end{abstract}

\begin{abstract}
Present days, often called Information Age, or Computer Age are characterized by the decrease of natural social interaction between people. Thus the social potential of sports activities is shifting to the centre of scholar's attention. Not only the worldwire spread, popularity, active participating and its media coverage make sports the social phenomenon of the day. Various aspects of sport make it possible to influence the society and visa versa.

The research of socializing power of sports has traditionally differed between socializing into sports, socializing during sports, or through sport and finally socializing directly in sports. However nowadays, the width of sport disciplines that involves wide range of physical activities at various intensity levels makes it almost impossible to make any generalizations based on results coming from more sport fields (individual, collective) and foremost performance levels (recreational, performance level, top athlete level). Moreover, reasons for getting involved in sport activities can be rather individualized. This implies foremost the necessity to offer kids and the youth colourful variety of sport activites in all performance levels.
\end{abstract}

Klíčová slova: $\quad$ pohybová aktivita, sportovní aktivita, společnost, děti, mládež

Key words: $\quad$ physical activity, sport activity, society, children, youth

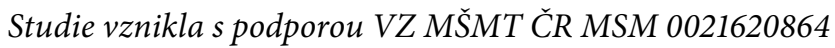

\section{ÚVOD}

O významném a de facto nezastupitelném postavení pohybových, resp. sportovních aktivit ve společnosti pojednává řada dokumentů na mezinárodní úrovni - Evropská charta sportu pro všechny (1974, in: Králík, 2001); Mezinárodní charta tělesné výchovy a sportu (1978, in: Králík, 2001); Evropská deklarace urbanistických práv (MŠMT, 1992); Evropská charta sportu (MŠMT, 1994); Evropský manifest o mladých lidech a sportu (MŠMT, 1995); Modifikovaný návrh směrnic pro sport dětí a mládeže (ČSTV, 1998) Evropského sdružení národních nestátních sportovních zastřešujících organizací (European 
Non-Governmental Sports Organisations) ${ }^{1}$; Světový manifest tělesné výchovy 2000²; Bílá kniha o sportu (MŠMT, 2007). V českých podmínkách jde především o Zákon o podpoře sportu ${ }^{3}$. Z dalších vládních dokumentů lze uvést především materiál Ministerstva školství, mládeže a tělovýchovy (MŠMT) Směry státní politiky na léta 2004-2006 aj.

Mnohé výzkumy z českého prostředí (např. Zich a Ungr, 1995; Slepička, 2000; Rychtecký et al., 2000, 2006; Sak, 2006) potvrzují význam sportu v hodnotové orientaci zejména mladé generace i současné vysoké zastoupení sportu mezi aktivitami provozovanými ve volném čase. Dle Jansy (2002) si více než $73 \%$ české mládežnické populace (15-18 let) uvědomuje důležitost sportu a pohybových aktivit z celospolečenského hlediska, tzn. pro všechny věkové skupiny obyvatel. V tomto kontextu se sport stává velice zajímavým ze sociální a pedagogické perspektivy.

$\mathrm{Na}$ významnost sportu v celospolečenském kontextu poukazují mnohé zahraniční studie. Např. podle Weisse (2000) sport zrcadlí společnost a může do určité míry přispívat k jejím proměnám. Při velkých sportovních událostech, ale i masovém sportování ve volném čase lze o sportu mluvit jako o společenském fenoménu. Význam sportu je možné vnímat jak v oblasti kulturní, sociální, mediální, tak i ekonomické. Patriksson (1994) uvádí, že sport jakožto „společenská instituce“ takovéto velikosti a významu má určitá specifika, která ostatní lidské aktivity nemají či je mají v menší míře. Rozšířenost sportu zvláště mezi dětmi a mládeží vede $\mathrm{k}$ přesvědčení, že by měl odrážet mnoho běžných norem a hodnot vyzrálé společnosti, a tudíž přispívat $\mathrm{k}$ reprodukci příznačných společenských hodnot.

\section{SOCIALIZACE}

Jeden z prvních, který koncem 19. století představil termín „socializace“ na vědeckém poli, byl francouzský sociolog Emile Durkheim (in: Patriksson, 1994). Existuje mnoho úhlů pohledu na definování termínu socializace. Dle Hurrelmana $(1988$, s. 2) je socializace:

„Proces vzniku, formování a vývoje lidské osobnosti v závislosti na a v interakci s lidským organismem na straně jedné, a společenských a ekologických životních podmínkách, které existují v dané době během historického vývoje společnosti na stranè druhé."

Keller (2002) chápe socializaci jako univerzální kulturní prostředek k zajištění kontroly chování a myšlení členů společnosti. Socializací prochází každý jedinec, má-li se stát sociální a kulturní bytostí. Cílem socializace je zformovat bytost, která se bude i o samotě chovat tak, jako by byla pod stálým dohledem ostatních členů skupiny. Toho lze dosáhnout tehdy, přijme-li jedinec za své nejen vědění, ale též hodnoty, normy a měřítka své kultury. Pro každou společnost představuje socializace zcela základní problém, a to ze dvou důvodů. Bez uspokojivé socializace zůstávají jedinci neschopni vstupovat do běžných interakcí s dalšími členy skupiny. Vznikají sociálně narušení jedinci, kteří nedokáží respektovat normy běžného soužití a zapojovat se do kolektivních akcí. Druhým důvodem je fakt, že společnost bez socializace není schopna předat své základní normy a hodnoty následující generaci a rozpadá se. V procesu socializace se přenášejí nejen kulturní hodnoty, ale také sociální nerovnosti. Sociologické výzkumy ukazují, že možnosti změny sociálního zařazení - sociální mobilita - jsou malé, ale samozřejmě záleží na postavení a typu společnosti. Dalším znakem socializace, který má pro společnost negativní dopad, je fakt, že je možné se velmi rychle „socializovat“ do skupiny, jejíž hodnoty a normy jsou v rozporu s celospolečenskými normami a hodnotami (extremistické skupiny, bezdomovci, drogově závislí atd.).

Jiná definice socializace se pokouší zachytit její interakci s okolím. Vyjadřuje, že socializace spočívá v procesu „vynořování se, formování a rozvíjení lidské osobnosti“. Na jedné straně v závislosti na interakci s lidským organizmem a na druhé straně se současnými společenskými a ekologickými podmínkami pro život, i ve vztahu s historickým vývojem dané společnosti (Hurrelman, 1988, s. 2).

Heinemann (1988) popsal čtyři dimenze socializace, které jsou důležité jak obecně, tak v kontextu sportu. První z nich je normativní konformita. Tím jsou míněny hodnoty, normy, symboly a techniky,

1 Za Českou republiku je členem ENGSO Český svaz tělesné výchovy.

2 World Manifesto of Physical Education FIEP 2000.

3 Zákon č. 115/2001 Sb., o podpoře sportu ve znění novely zákona č. 219/2005 Sb. 
které jsou přenášeny v dané společnosti a které se jednotlivec učí a přejímá je jako daná pravidla. Druhá dimenze je sebeidentita, což je schopnost harmonicky kombinovat očekávání a požadavky sociální role s osobností jednotlivce (potřebami, práními a zkušeností). Třetí dimenzí je kompetence čili schopnost autonomního jednání, reflektivní aplikace sociálních norem o zvládání konfliktů. Ve zkratce to znamená být nezávislý a užívat reflektivně a flexibilně společenské normy. Čtvrtým aspektem je solidarita, což je schopnost spojit a integrovat sebeidentitu a kompetenci se svými společenskými závazky.

Podstatné je také zmínit některé mechanizmy socializace, které úzce souvisí s oblastí sportu a pohybových aktivit. Za základní lze považovat identifikaci a imitaci. Identifikace se dá považovat za formu sociálního učení. Identifikací se zde rozumí ztotožnění se s někým, resp. srovnávání se vzorem, přijetí určitého vzoru, referenční skupinou. Oproti identifikaci se imitace vztahuje k dílčím projevům chování, jde o učení na základě pozorování. Zato identifikace znamená hluboké ztotožnění se, znamená chovat se tak, jak by se choval objekt identifikace na místě identifikující se osoby (Nakonečný, 2000). Např. nový hráč sportovního týmu se identifikuje se zkušeným kapitánem, čili chová se tak, jak by se choval onen kapitán na jeho pozici. Identifikace však také znamená některé imitační prvky vynechat, nebot by to znamenalo vznik určitých konfliktů. Např. daný nováček nemůže imitovat všechny dílčí projevy chování kapitána, jako např. hecování a vůdcovské postavení v týmu. V identifikaci se tedy uplatňuje zobecněné pozorování, které se však může uplatňovat i v imitačním učení, protože i tam platí princip generalizace. Imitace se dá také v širším smyslu chápat jako nápodoba jednání, resp. chování vůbec (např̀. způsobu řeči).

Jakmile se děti blíží k adolescenci, jsou velice silně formovány vrstevnickými skupinami. Tyto skupiny mají silný vliv na jejich hodnotovou orientaci, postoje a chování, které může být v rozporu s představami dospělých.

I po dosažení dospělosti se jedinec musí přizpůsobovat novým situacím. Socializace je zpětnovazební proces - i dospělí se mohou učit od mladých ${ }^{4}$. Rodinná výchova se dnes již relativně slabě váže na zkušenosti a postupy předchozích generací. Nabývá multidimenzionální podstaty a dochází v ní i k výraznější zpětné socializaci (Sekot, 2008), kdy se rodiče učí od svých potomků, což je dáno zejména nebývalým rozvojem informačních a komunikačních technologií. $V$ těchto oblastech má mládež poměrně výrazně navrch nad dospělou populací. Další doménou mladých je jednodušší a rychlejší osvojení cizích jazyků. Pigeassou (2000, s. 20-21) uvádí teoretický rámec procesu socializace následovně:

„Socializace může být v podstatě chápána bud' jako přijetí pravidel pro dospělé mladými lidmi nebo jako budování norem mezi vrstevníky a nakonec také jako proces, $k d y$ se dospělý jedinec a mladý jedinec navzájem socializují."

Obecný náhled různých vědních oborů na socializaci přináší Patriksson (1994, s. 4):

„Pedagogičtí výzkumníci často zdưrazňují plánovanou formální socializaci, psychologové se soustředí na jednotlivé faktory - osobnost, kognitivní vývoj, sociologové mají tendenci zdưrazňovat sociální struktury ve společnosti, zatímco predstavitelé ze sociální antropologie často dávají prednost kulturním faktorům."

Mezi hlavní cíle socializace tedy patři naučit jedince správně se chovat v různých sociálních rolích; naučit se určitým dovednostem (mj. i sportovním); vzbudit u jedince aspirace; vypracovat u člověka schopnost vzdát se určité potřeby nebo její splnění odložit na pozdější dobu či ji substituovat něčím jiným. Efekt socializačního procesu se spatřuje především v úrovni psychosociální vyspělosti - zralosti jedince. Adekvátní průběh socializace se z psychologického hlediska projevuje kongruencí dílčích rolí jedince, kongruencí sociální role a osobnostního sebepojetí, kongruencí JÁ a MY, adekvátní úrovní psychosociální zralosti.

Socializace je tedy dlouhodobý, celoživotní nepřerušovaný a časově neomezený proces, který je všudypřítomnou součástí lidských zkušeností. Jde o osvojování hodnot a norem, při němž dochází k přeměně přírodního tvora - novorozence v cílevědomě jednající lidskou - společenskou bytost. Jedinec se v tomto procesu učí být členem společnosti, reagovat na podněty z okolí v souladu se všeobecným očekáváním, tím se adaptuje na prostředí a jeho osobnost se přizpůsobuje daným podmínkám, jinými slovy „učí

4 U dětí se hovoří o socializaci primární (do 3 let) a sekundární (od 3 let), u dospělých osob o terciární socializaci. 
se hrát role v různých pozicích “. Během socializace aktivně formulujeme myšlenky kdo jsme a co je podstatné $\mathrm{v}$ našem žití (Coakley, 2001). Socializace je proces, $\mathrm{k}$ němuž dochází vědomě a záměrně (v rodině nebo ve škole), ale i mimovolně, vzniká interakcemi, kdy se člověk koriguje ve vztahu k ostatním, kdy také uplatňuje svou schopnost vcítění se do situace druhého člověka - empatii. Probíhá plánovitě - systematicky i nahodile - improvizovaně, ale i intuitivně. Na socializaci se podílí řada společenských institucí a organizací, což je dokladem závažnosti tohoto procesu pro reprodukci a stabilitu společnosti jako celku. Mezi nejvýznamnější socializační činitele lze uvést rodinu, školu, zájmové aktivity - např. sportovní kluby, vrstevníky, kamarády, média, zaměstnání, obec atd.

Sport je často zmiňován jako důležitý socializační činitel (Patriksson, 1979, 1994; Weiss, 1987; Hogg and Abrams, 1988; Greendorfer, 1992; Hendry, 1992; Slepička, 2000; Dohnal, 2002; Sekot, 2003, 2008). Tento socializační potenciál sportovních a pohybových aktivit se zejména $\mathrm{v}$ souvislosti se současnou informační společností stává velmi zajímavým, protože patrně ubývá přirozeného sociálního kontaktu mezi lidmi, kteři si stále více zvykají na „setkávání na dálku“ prostřednictvím nejrůznějších moderních komunikačních technologií.

\section{SPORT}

\subsection{Definice a dělení sportu}

Sport má mnoho společných znaků se základním přirozeným socializačním mechanismem každého jedince, kterým je hra ${ }^{5}$. Vždyt někteři autoři dokonce dávají mezi tyto dva pojmy rovnítko (Choutka, 1978). Sport a hra mají mnoho společných rysů: dobrovolnost, prožitek z činnosti, určitá pravidla, časové a místní ohraničení. V Anglii zase můžeme nalézt rozdělení sportovních aktivit na sport a hry - sports and games (napr. atletika, plavání versus fotbal, tenis).

Všeobecně lze konstatovat, že ve světě existují dvě pojetí sportu: první z nich akcentuje hru, soutěž a výkon. Toto pojetí sportu, které znamená soutěžní sport se všemi jeho atributy (trénink, výkon, soutěž apod.), preferovali např. Choutka a Dovalil (1991), Dovalil (2002). Druhý př́stup (např. Sekot, 2009) je v souladu s etymologií slova sport, které je latinského původu (desportare) a znamená rozptylovat se, bavit se. V tomto širším pojetí je sport definován v Evropské chartě sportu (MŠMT, 1994; čl. 2a):

„Sportem se rozumí v̌̌echny formy tělesné činnosti, které at' již prostřednictvím organizované účasti či nikoli, si kladou za cíl projevení či zdokonalení tělesné i psychické kondice, rozvoj společenských vztahů nebo dosažení výsledkư v soutěžích na všech úrovních."

$\mathrm{S}$ diverzifikací sportu $\mathrm{v}$ posledních letech (vznik nových sportovních odvětví, často s prvky zábavy apod.) se zdá, že širší pojetí sportu nabývá stále více na platnosti.

V současnosti se lze v ČR opřít zejména o Zákon o podpoře sportu ze dne 28. února 2001 (ve znění novely č. 219/2005 Sb.), který sportu přisuzuje poměrně výsadní postavení ve společnosti, jelikož ho vymezuje jako veřejně prospěšnou činnost.

„Pro účely tohoto zákona predstavuje pojem sport všechny formy tělesné činnosti, které prostřednictvím organizované i neorganizované účasti si kladou za cíl harmonický rozvoj tělesné i psychické kondice, upevňování zdraví a dosahování sportovních výkonů v soutěžích všech úrovní.“( $(2$, odst. 1)

V tomto širším smyslu je sport chápán i v předkládaném článku.

Sportovní aktivity lze třídit dle mnoha hledisek: období (letní, zimní), prostředí (primárně na venkovní, sálové), počtu zúčastněných osob (individuální, kolektivní), formy (organizované, neorganizované). Ve vztahu k socializačním mechanizmům jsou zajímavé především rozdíly mezi organizovaným a neorganizovaným sportem a zda se jedná o sport individuální či kolektivní. Dalším podstatným atributem sportu je jeho přívlastek z hlediska dosahovaného výkonu na rekreační, výkonnostní a vrcholový (nebo též profesionální) sport. Je tedy zřejmé, že pojem sport znamená pro různé jedince něco docela jiného,

5 Již G.H. Mead poukázal na to, že podstatná součást dětského učení přijímat sociální role probíhá v průběhu hry. Odlišil hru-play a hru-game: první označuje prosté „hraní si na něco“, spočívající v napodobování rolí dospělých, druhá pak „hraní něčeho“, což zahrnuje složitější systém pravidel, která musí dítě pochopit a podvolit se jim. 
a zdá se, že se tato skutečnost nedostatečně odráží ve výzkumných záměrech zaměřených na sport a socializaci, alespoň co se týče jejich interpretace a generalizace. Pro profesionálního sportovce znamená sport práci, způsob obživy, pro někoho jiného - zejména děti, mládež, seniory - může být zase vhodným způsobem k seznámení s novými lidmi, možnost jít ven apod. tzv. „společenský model sportu“. I proto je vhodné v mnoha případech uvádět bližší charakteristiku - přívlastek sportu.

Sarah Gilroy (1999) rozlišuje dva převládající modely sportu:

a) společenský model sportu - je provozován zejména ze společenských důvodů; pro radost a s malým tlakem na výsledek; dobrý způsob, jak se stýkat s lidmi; účastníkům přináší dobrou náladu; soutěžní element je potlačen a je v tomto modelu sportu až druhotný.

b) závodní model sportu - na prvním místě je soutěživost; důraz je kladen na výsledek; nezřídka „vyhrát za každou cenu“, všemi dostupnými prostředky (povolenými i zakázanými); tento model sportu je velmi strukturován; na nejvyšší úrovni, zejména v některých mediálně atraktivních sportovních odvětvích, se točí velké finanční objemy.

\subsection{Sport jako společenský fenomén}

Sport sám o sobě byl od 19. století důležitou subkulturou západní společnosti. Postupem doby se sport stal celosvětovou subkulturou, jak dokládají např. olympijské hry, světové šampionáty, tenisové turnaje, ale i různá exhibiční klání. Sport lze proto bez větší nadsázky označit jako fenomén v nejširším slova smyslu. At̉ už máme na mysli oblast kulturní, společenskou, mediální či ekonomickou.

Pro označení sportu jako fenoménu, které je platné téměř celosvětově, ale i u nás, můžeme nalézt další řadu dokladů. Od divácké sledovanosti největších sportovních událostí typu olympijských her či mistrovství světa přímo na stadionech, ale i na velkoplošných obrazovkách na náměstích velkých měst, ve společenských zařízeních (restaurace, bary), tak i doma na televizních obrazovkách (dnes zcela samozřejmě i na internetu). Sledování významných sportovních událostí má přinejmenším znatelný „sdružovací “ efekt fanoušků při hromadném sledování těchto sportovních klání. Navíc jak většina českých a slovenských sportovních fanoušků (68\%) uvedla, sportovní diváctví je pro ně významný způsob trávení volného času (Slepička, 1995, s. 275).

Weiss (2000, s. 276) uvádí tvrzení Duncanové: „... sportovní diváctví získalo zájem a podporu miliónu lidí a sport přesahuje hranice hry samotné, protože vytváři literaturu, písnè, mýty a významné osobnosti zasahujicí do mnoha oblastí veřejného života."

Tzv. „triumfální návraty“ zejména reprezentačních sportovních výběrů (ale i klubových) také dokládají, jakým je sport fenoménem, který dokáže doslova pohltit velkou část populace, kterou sport ani de facto nezajímá. Takže se celkem logicky můžeme domnívat, že sport má určitá specifika, která ostatní lidské aktivity nemají či je alespoň mají v menší míře (Patriksson, 1994). Tento divácký zájem na „globální úrovni je ovšem platný i na regionálních úrovních, jako př́klad lze uvést fotbalové derby lokálních rivalů, což je mnohdy považováno za „událost roku“ daných obcí či regionu.

Dalším pádným dokladem může být mediální prostor věnovaný sportovním událostem ve většině hromadných sdělovacích prostředků. V mnoha zemích tvoří objem finančních prostředků nabalující se na „sportovní byznys“ nezanedbatelnou část všech finančních toků. At již jde o „prrímé produkty“, jako vstupenky, televizní práva, repliky dresů, textilu, nebo produkty vyloženě „nepřímé“, jako jsou například televizory, projektory apod., kdy prodej tohoto zboží před významnou sportovní událostí stoupá geometrickou řadou.

Do samostatné kategorie patří zapojení měst (resp. často celých států) do procesu kandidatury na pořádání velkých sportovních akcí, již zmíněných olympijských her či světových šampionátů (v ČR čerstvá zkušenost $s$ mistrovstvím světa $v$ klasickém lyžování v Liberci). Na této vrcholné sportovní úrovni jsou nezbytné záruky vlády státu již při kandidatuře. Už samotná př́prava kandidatury je de facto celospolečenská záležitost (viz např. Praha Olympijská, liberecký světový šampionát apod.). Úspěšná kandidatura na pořádání olympijských her znamená investice v řádech desítek miliard korun (viz např. olympijské hry v čínském Pekingu v roce 2008) do různých oblastí, zejména do infrastruktury v nejširším slova smyslu. Bez nadsázky lze tedy konstatovat, že sportovní akce tohoto typu se osobně, at' už př́mo nebo 
nepřímo, a to pozitivně či negativně, dotknou doslova každého obyvatele konkrétní metropole, potažmo hostitelského státu. Takže podobně jako politika ovlivňuje životy těch, kteří se o ní vůbec nezajímají, tak stejně lze říci, že sport jakožto sociální instituce má rovněž celospolečenský dopad, a to i na ty, kteří vlastně v životě nesportovali. Na komunální úrovni je politický proces významným faktorem rozvoje a údržby sportovišť v daném městě (např. Houlihan and White, 2002). Jako další důkaz můžeme uvést zvýšenou frekvenci obnovy sportovní infrastruktury, včetně slavnostního otevření, pro obyvatele měst a obcí spojenou s předvolební kampaní kandidátů do volených orgánů v dané lokalitě.

Tím, jak je sport nepochybně společenským jevem, tak je zároveň determinován, ale i ovlivňuje dění ve společnosti. Celospolečenský význam sportovních událostí je umocněn třeba i návštěvami politiků a státníků na těchto akcích, ale tím to končit nemusí. Politici a státníci přijímají úspěšné sportovce - u nás zpravidla reprezentanty naší země na oficiálních návštěvách; nemálo „hvězdných“ sportovců obdrží různá státní ocenění apod. Ve Spojených státech amerických má velkou tradici přijímání úspěšných sportovců prezidentem, který přijímá v některých sportovních odvětvích i vítězné týmy „pouze“ národních soutěží. Dále např. americký prezident tradičně provádí slavnostní nadhoz při zahájení sezony nejvyšší ligy baseballu (MLB).

Heinemann (1986) vyvozuje z různých uváděných definic sportu, že sport je ideální činnost, jak trénovat sociální chování.

\section{SOCIALIZACE SPORTEM}

$\mathrm{Na}$ významnost sportu $\mathrm{v}$ celospolečenském kontextu poukazují mnohé zahraniční studie. Např̀ podle Weisse (2000) sport zrcadlí společnost a může do určité míry přispívat $\mathrm{k}$ jejím proměnám. Rozšířenost sportu zvláště mezi dětmi a mládeží vede k závěru, že musí odrážet mnoho běžných norem a hodnot vyzrálé společnosti, a tudíž přispívá k reprodukci příznačných společenských hodnot. Vždyt členem sportovního klubu někdy byla více než polovina českých obyvatel. Navíc školní tělesnou výchovou prošel téměř každý jedinec.

Sport je, zvláště v dnešní době, též velice široká oblast lidské činnosti (viz výše). Tudíž sloučením (nebo spíš znásobením) těchto dvou pojmů vzniká široké badatelské pole. Typickou studií z oblasti

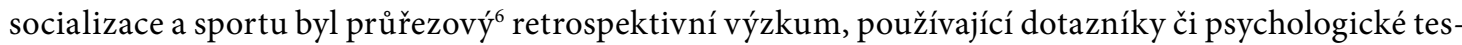
ty v jednom konkrétním časovém období a prezentující výsledky jako statistické průměry mezi sportovci a nesportovci. Takový design velmi ztěžuje podat přirozená vysvětlení a odhalit reciproční efekty socializačního procesu. Tak jednoduchá kategorizace na účastníky a neúčastníky sportu nemůže podchytit heterogenní sportovní zkušenosti, které jsou pravděpodobně skryté právě ve skupině účastnící se sportu (Patriksson, 1994).

Jiné dvě těžkosti vidí Coakley (1990). První z nich tkví v užívání neobjektivních výzkumných vzorků, které zahrnují jen špičkové atlety, což znamená, že participují jen „úspěšní“. To podává zkreslený obrázek o tom, co opravdu probíhá př̀i sportovní zkušenosti. Za druhé, sportovní aktivity jsou jedny z mála př́ležitostí, kdy mají jedinci veřejně šanci čelit náročným situacím, a tak ukázat „charakter“, který se ale pravděpodobně vyvinul během jejich přirozeného dozrávání.

„Bez ohledu na velikost rozdílů, zda se sportovci a nesportovci liší v některých osobnostních dimenzích, byly tyto rozdily prítomné před účastí ve sportu, nebo byly rozvinuty během sportovní zkušenosti? Toto je fascinující otázka z mnoha di̊vodů..."(Kremer and Scully, 1998, s. 18).

Socializace sportem je komplexní téma, které je velice obtížné nějakým způsobem shrnout. Motivační a kognitivní vývoj ovlivňují „tradiční“ socializační vlivy uvnitř specifických, společenských a kulturních souvislostí. Současný výzkum se snaží vysvětlit účast ve sportu bud’ užitím motivačního nebo socializačního přístupu. Proto výzkum nalézá převážně jednu z těchto domén (Patriksson 1994).

$6 \mathrm{~V}$ průřezové studii jsou sledovány předem definované populace (data jsou obvykle na individuální bázi) v určitém časovém okamžiku. Je tedy možné odhalit vztah (asociaci), ale často je obtížné rozlišit př́ícinu a následek (prokázat kauzalitu). Trochim and Donnelly (2007) stavějí průřezovou studii do opozice proti longitudinálnímu výzkumu. 
Prostředí sportovní socializace může obsahovat mnoho rozličných kategorií - sportovců, trenérů, manažerů, rozhodčích, diváků atd., a homogenních skupin jako vrstevníků, starších lidí, etnických minorit, handicapovaných jedinců apod. Co se děje v souvislosti se sportovním děním, jakým způsobem se sportovní lídři chovají, uvažují, jaké mají hodnoty, pak může významnou měrou souviset s následným jednáním dalších aktérů jakožto rodičů, diváků apod.

Důležitá je integrace sociologických a psychologických faktorů do teorie socializace. Jak např́íklad uvádí Pigeassou (2000, s. 23):

„Potiž je v tom, že sportovní činnost nelze teoreticky, oddělit od ostatních sociálních a kulturních praktik, se kterými je spojená... Analýza fenoménu sportu musí nepochybně překročit rámec kvantitativního prístupu a směřovat ke kvalitativnímu výzkumu, což provází lepši pochopení integračního charakteru sportovních aktivit."

Dále je ve výzkumech velmi těžko postihnutelné makroprostředí (makro úroveň - ekonomika, politická struktura, kultura), ale patrně hraje důležitou roli (Patriksson, 1994). Předchozí výzkumy ukázaly, že potřeba kompetence a úspěchu motivace má sklon odhalit, zda je socializace charakterizovaná soustavným úsilím dát dětem nezávislost a zvládnout více a více komplexních schopností.

Ve výzkumech je poměrně dlouhá tradice rozlišovat mezi socializací do sportu, socializací během či prostřednictvím sportu a dále socializací ve sportu. Socializační proces je oboustranná interakce, ale tato reciproční přirozenost je ve výzkumech prakticky ignorována (Patriksson, 1994).

\subsection{Socializace do sportu a di̊vody pro sportování}

Četné studie nasvědčují, že socializační proces začíná v ranném věku a je silně ovlivněn tím, zda se dítě zapojí do sportu a pohybové aktivity či nikoliv a zda si udrží zájem o tyto aktivity v dospívání a dospělosti (Smoll and Smith, 2002).

Socializační efekt pro děti a mládež vstupující do sportu je socializace do sportovní kultury, kde se učí jak být sportovcem. Nejvíce jedinců se seznámí se sportem v dětství. Postoje, které se rozvinou v tomto období, budou mít vliv pro budoucí život. Socializací do sportu se míní přijetí do sportovní skupiny, pokračování v činnosti a podpora dlouhodobé angažovanosti. Tak jako v jiných kulturách má i sport pravidla, která by se měla dodržovat. Hodně věcí se učíme pozorováním ostatních (např. Bandura, 1977). Tak jako jiné kultury, tak i sport má pravidla a hodnoty, které musí být nastaveny a zvnitřněny. Jsou zde také normy a hodnoty, jistě nepsané a často nevyjádřené, spojované s členstvím v konkrétním týmu či klubu: nošení klubového oblečení či výstroje; stálé tázání na rozhodnutí rozhodčího; hrát tvrdě, ale fér atd. Některé $z$ těchto norem a hodnot mohou být společensky přijatelné, jiné méně. Nováček příchozí do týmu se musí ztotožnit s těmito normami skupiny a rozhodnout se, zda je bude plně respektovat a stane se integrovaným členem týmu; některé bude odmítat, ale ještě zůstane členem; nebo opustí tým. To je většinou uvědomělý proces rozhodování, ale nemusí tomu tak být vždy.

Mnohé české výzkumy poukazují na podstatné místo sportu v hodnotové orientaci zejména mladé generace i na významné postavení sportu mezi aktivitami provozovanými ve volném čase (např. Zich a Ungr, 1995; Sak, 2006). Dále lze uvést např. výzkum Slepičky et al. (2000) z let 1998-99, který ukazuje na důležité postavení sportu ve struktuře volnočasových aktivit mládeže $-51 \%$ respondentů, což byla druhá nejčastěji uváděná aktivita po schůzkách s přáteli. Též Rychtecký et al. $(2000,2006)$ hovoří o významném postavení sportu ve volnočasových aktivitách mládeže (9-19 let). Za důležitý (a spíše důležitý) označilo sportování více než $80 \%$ respondentů mezi 12-15 roky z 2564 dotázaných mladších adolescentů (Flemr, 2009). Dle Jansy (2002) si více než 73 \% české mládežnické populace (15-18 let) uvědomuje důležitost sportu a pohybových aktivit $\mathrm{z}$ celospolečenského hlediska, tzn. pro všechny věkové kategorie. Na Fakultě elektrotechnické ČVUT v Praze si dokonce 97,5\% vysokoškoláků ze 1616 členného souboru myslí, že tělesná výchova a sport jsou nedílnou součástí životního stylu (Valjent, 2004).

Pravidelné aktivní cvičení v šetření Jansy (2002) uvedlo více než $65 \%$ respondentů (15-18 let). Členství ve sportovních organizacích bylo zjištěno u $29 \%$ respondentů. Dle Jansy et al. (2005) nejvíce provozují organizovaný sport 13-15letí chlapci (65,8 \%). Dívky (7-15 let) navštěvovaly pravidelně sportovní klub v rozmezí 38,9-41,4\% ve všech sledovaných věkových kategoriích (7-15 let). 
Důležitými otázkami k diskuzi jsou v této souvislosti proč, jak a s jakým efektem se jedinci stávají zapojenými ve sportu a zda pokračuje jejich angažovanost v pozdějším období života. Jedním z klíčových elementů dětského zapojení do sportu je bezesporu rodina (Rowley, 1986; Jansa et al., 2005), je znám především velký vliv otců (nap̌r. Lewko and Greendorfer, 1988). Dle Greendorfer (1992) je socializační efekt sourozenců ve sportu menší než rodičů. Coakley (in Sekot, 2003) uvádí, že participace dětí a mládeže ve sportovních aktivitách je ovlivňována členy rodiny, kamarády, názorovými vůdci, životními vzory, nejbližší komunitou, a v neposlední řadě i vnímavostí potenciálního dětského účastníka sportovních aktivit a přirozeně i dostupnou př́ležitostí. Děti, které si myslí, že se zapojily do sportu nezávisle na okolí, mají o sobě větší mínění - klasifikují své dovednosti jako „lepší než průměr“, „jeden z nejlepších hráčư - a zdá se, že ze sportu mají větší požitek. Na rozdíl od těch, které jsou si vědomy, že je někdo ovlivnil (McGuire and Cook, 1983).

Velmi důležitým prvkem socializace je motivace. Většina výzkumníků při pokusech vysvětlit, proč děti a mládež začínají se sportem, má vybránu teorii potřeby a motivační teorii nebo socializační teorii jako jejich východisko. Děti a mládež mají rády sport $\mathrm{z}$ mnoha různých důvodů, které lze rozdělit do tř́ základních kategorií (Whitehead, 1988): a) být schopen dělat něco dobře; b) být zapojený nebo respektovaný ostatními; c) demonstrovat přesilu.

Výzkumy tedy obecně ukazují, že se děti účastní sportu kvůli zábavě, zlepšení schopností, př́íslušnosti ke skupině, úspěchu a získání uznání, zabavení se a vzrušení.

Důvody pro opouštění sportu zahrnují provozování jiných aktivit, nedostatek vzrušení, úspěchu, přílišný tlak, ztrátu zájmu, odchod kamarádů, vysoké výdaje, zranění, práce a problémy s vybavením nebo nedostatečnou podporou. Všechny tyto výsledky naznačují, že není jednoduché pochopit dětskou motivaci ve sportu. Děti a mládež mají různé důvody pro to, co dělají, a některé z nich se rychle mění. To je zcela v souladu s tvrzením Patrikssona (1994), který konstatuje, že při zapojení dětí do sportu se většinou jedná o kombinaci více faktorů. Coakley (2001) učinil závěr, že formální sportovní soutěže nejsou vhodné pro děti mladší 8 let kvůli jejich omezené schopnosti osvojit si různé úlohy a chápání, o čem je vlastně ta soutěž. Vysokoškolští studenti ČVUT v Praze pak udávají následující pořadí důvodů, které vedly k ukončení závodní sportovní činnosti: nedostatek volného času, vysoké studijní zatížení, změna v motivaci, rozpad party, zranění, výkonnostní stagnace, změna místa bydliště kvưli studiu (Valjent, 2009).

Dále je vhodné upozornit na diference mezi pohlavími (např. Koivula, 2000; Sekot, 2008), které jsou již patrné ve vnímání dětí jejich rodiči (Kremer and Scully, 1998, s. 164): „Když se chlapec zraní při fotbale, tak je mu řečeno, že ,velcí kluci nebrečí, a když si jde dívka hrát ven s kamarádkami, tak je jí řečeno, aby se neušpinila." Chlapci (11-19 let) inklinují k očekávání, že úspěch ve sportu povede k externím odměnám jako je sláva a popularita. Na druhé straně dívky sportovní aktivity vnímají především ve spojení se sebeuspokojením. Vítězství je zjevně důležitější pro chlapce a společenské uznání pro dívky (Greendorfer and Swing, 1981). Obecně lze konstatovat, že soutěžení a kompetitivní sport více přitahuje chlapce než dívky (např. McGinnis et al., 2003; Rychtecký, 2000, 2006).

Pozitivní i negativní účinky, které jsou asociovány se sportem, nevyplývají samy o sobě, ale z individuální sportovní zkušenosti. $Z$ toho vyplývá důležitost a vliv trenérské práce v mládežnickém sportu (více např. Sekot, 2008).

I v prŕpadě sportu ve spojitosti s adolescenty platí zřejmě jakási zlatá střední cesta, která je rozdílná pro různé věkové skupiny i pro každého jedince. Obecně je možné konstatovat, že jestliže je sport pro adolescenty příliš soutěživý, tzn. vytváří příliš tlaku, tak opouštějí sportovní aktivity a snaží se nalézt jinou zábavnější činnost. Na druhou stranu jej opouští rovněž z důvodu nedostatku vzrušení, výzvy a v neposlední řadě chtějí mít také možnost napodobit své vzory v jiných oblastech lidské činnosti.

Mnoho studií dokumentuje, že sport je výborným prostředkem k navázání nových sociálních kontaktů, napomáhá učení se různým sociálním rolím, hodnotám a pravidlům. Sport je otevřen pro všechny bez ohledu na barvu pleti, vyznání či politické přesvědčení, pro děti, mládež, dospělé i seniory. Sportovní diváci i aktivní sportovci mohou pocházet $\mathrm{z}$ velmi odlišných poměrů, mohou být na naprosto odlišné intelektuální úrovni, přesto je sport, jako jedna z mála aktivit, dokáže spojovat, a dokonce si díky sportu „mají co říci“. Toto tvrzení dokládá již např. Patriksson (1979), který ve švédských podmín- 
kách uvádí, že pro děti ve věku 7-12 let nebyla pro účast v soutěžích rozhodující příslušnost ke společenské tř́íě. Tato situace byla ještě platná v 9. ročníku (tzn. 14 let). Taktéž Flemr (2009) neprokázal těsnější vztah mezi účastí mladších adolescentů (12-15 let) ve sportu a socioekonomickým zázemím jejich rodiny. Navíc dle Jansy (2002) více než 80 \% české mládeže (15-18 let) nesouhlasí s tvrzením, že sport a pohybové aktivity jsou jen pro majetnější jedince. Na druhé straně závislost socioekonomického statusu rodiny na participaci ve sportovních aktivitách adolescentní populace potvrzují např. Barnekow-Bergkvist (1997a, 1997b), Raudsepp and Viira (2000).

Naopak u dospělé populace je situace celkem jednoznačná - vyšší socioekonomický status zpravidla znamená vyšší účast ve sportu (Weiss, 2000; Slepička et al., 2001; Špaček, 2007). Tento fakt potvrzuje Flemr (2009), nebot byl zjištěn vztah mezi ekonomickým zázemím rodiny a současnou sportovní aktivitou alespoň jednoho z rodičů mladších adolescentů (korelace 0,21 ). Navíc korelace mezi současnou a dřivější sportovní aktivitou alespoň jednoho z rodičů mladších adolescentů poměrně výrazně stoupá s jejich dosaženým vzděláním. Toto zjištění je v př́mém souladu se závěry Slepičky a Slepičkové (2002), kteří uvádějí, že jedinci s nižším stupněm dosaženého vzdělání preferují názor, že sport je záležitostí spíše jen pro mladé.

V celém kontextu je již zřejmě problematický koncept socioekonomického statusu (Kreidl a Hošková, 2008) - zda jej pojímat jako výši přímu, vzdělání rodičů, jejich povolání, kvalitu bydlení, vlastnictví automobilu, či kombinaci výše uvedeného atd. Každé hledisko je odlišné v rozdílných kulturních podmínkách.

$\mathrm{Na}$ druhou stranu už i ve sportu dochází k určité exkluzi, která je dána především velkou finanční náročností některých sportů. Stupeň této exkluze je opět velmi variabilní, liší se kultura od kultury, země od země atd. Jako př́ílad lze uvést golf, který je v našich podmínkách vnímán jako „kapitalistický“ sport (a skutečně je nákladný), kdežto ve Švédsku je to dostupná aktivita pro všechny.

Sportovní aktivity také velice napomáhají při socializaci např́íklad handicapovaných jedinců, uplatňují se i různé resocializační terapie pro drogově závislé či delikventní jedince. Avšak i zde existují určitá rizika a omezení.

Lee (1999) zjistil, že mladí sportovci patrně vyjadřují hodnoty, které jsou specifické pro daný sport nebo přinejmenším obzvlášt důležité ve sportovním nasazení. To je v protikladu předpokladům zjištěných Rokeachem (1973) a ostatními vědci v oblasti hodnot, již usuzují, že jsou hodnoty univerzální, tedy aplikovatelné ve všech oblastech života. Nicméně to ospravedlňuje pohled těch, kteří doporučují identifikační hodnoty specifické skupinám, o které se výzkumník zajímá.

Za druhé, analýza četnosti výskytu naznačuje rozdíly mezi pohlavími a hráči různých sportů. Prožitek byl zmíněn častěji mezi tenisty než fotbalisty. Fotbalisté byli více zaujati kolektivními hodnotami jako přizpůsobení, podrobení a týmový duch. To naznačuje, že je zde význam kultury, která je asociována s různými sporty, které mohou být přeneseny trenéry (Lee, 1999).

Za třetí, nejčastěji zmíněné hodnoty byly vítězství, zábava a členství v týmu („sportmanship“). Avšak není možné v této době vystihnout vzájemnou důležitost těchto hodnot. Je dostatečné ŕíci, že je v souladu s množstvím dostupných výzkumů, že se mladí lidé primárně zajímají o zábavu a uspokojení ve sportu. Problémem je, že se děti těši $z$ různých věcí okolo sportu, a ne vždy lze dobře rozčlenit jejich pocity (Wankel and Kreisel, 1985). Zdá se, že tyto hodnoty mají u mladých sportovců mezinárodní platnost (Lee, 1999).

Výsledky studie Barnekow-Bergkvist (1996) ukazují, že zakotvení vlastní pohybové aktivity ve volném čase v dětství je důležitější než jen získání príínivých postojů ke sportovním aktivitám.

Zastánci dětského sportu vidí, že je to zaslíbená země, kde účastníci rozvíjí budoucí dovednosti, členství v týmu, sebeúctu, samostatnost, loajalitu a příslib znamenitosti. Odpůrci sportu v něm vidí zdroj nespravedlnosti, argumentují tím, že vítězství „za každou cenu“ směřuje k násilí, podvádění, dopingu a rozporu.

Je evidentní, že oba tábory - zastánci i odpưrci dětského sportování - se domnívají, že tyto pozitivní i negativní efekty nejsou automatické. Pozitivní i negativní účinky, které jsou asociovány se sportem, nevyplývají samy o sobě, ale z přirozenosti sportovní zkušenosti. $Z$ toho jasně vyplývá důležitost a vliv trenérské práce $\mathrm{v}$ mládežnickém sportu. 
$\mathrm{Na}$ děti, pro které hraje sportování důležitou roli, může mít vážný dopad to, jak vidí samy sebe. Způsob jakým děti vnímají samy sebe, může hrát důležitou roli při jejich účasti ve sportu (Australian Sports Commision, 1991; Weiss at al., 1990). Australská studie zřetelně odhalila, že nízko vnímaná zdatnost nebo fyzická sebeúcta jsou podstatnými činiteli neúčasti.

Schelin $(1985,49)$ uvedl důležitost nazírání na účast ve sportu jako proces skládající se z několika fází: a) vyzkoušením sportu; b) počátek sportu; c) setrvání se sportem; d) pevné zakotvení ve sportu.

Zvláště důležité je diferencovat mezi „vyzkoušením sportu“ a „počátkem sportu“, protože jsou pravděpodobně ovlivňovány odlišnými faktory. „Vyzkoušení“ je často ovlivněno idoly a médii, zatímco více rozhodné účastnění se ve sportu je pod vlivem faktorů uvnitř okolního prostředí.

Rozmanitost sportovních aktivit pro dnešní mládež je rozsáhlá, ale je dostupná jen v př́padě, že rodiče jsou schopni je podporovat $s$ dopravou, vybavením či různými poplatky (členské př́spěvky apod.). Vyvstává až otázka, zda portfolio sportovních aktivit není přespříliš široké, právě ve vztahu $\mathrm{k}$ „socializačním schopnostem“ sportu, což může být problémem zejména v menších sídlech např. při „sestavení“ týmu pro kolektivní sport-hru.

\subsection{Socializace ve sportu a během sportu}

Socializace ve sportu se soustředí na to, co je skutečně ve sportu naučeno samo o sobě, bez nezbytně hledajících užitečností mimo sport. Když se analyzuje socializace během sportu, je obvykle kladen důraz na účinky sportovní účasti zvláště do dalších oblastí života, zda je sport užitečný pro nějaké další oblasti, tzn. zda má „přenosnou hodnotu“.

Jedná se o velmi široké spektrum výstupů - motorické dovednosti, sociální kompetence pro získání hodnot a norem, respektování pravidel apod. Během socializace ve sportu se také jedinci učí o postavení uvnitř sportovního týmu a přebírají jednotlivé role. Jsou zde formální role jako kapitán nebo trenér a neformální role jako bavič, smiřovatel nebo hecír. Ve srovnání se socializací do sportu bylo zřejmě provedeno méně výzkumů, což je patrně dáno obtížným designem výzkumu a metodologickými úskalími. Přesvědčení, že účast ve sportu a dalších pohybových aktivitách přináší mnoho výhod pro mládež i dospělé, je dlouhodobé. Jeden z největších užitků získaných ze sportovní účasti pro děti je, že naučené sportovní dovednosti mohou následně využít v dospělosti při sportování.

Aktivní účasti ve sportu jsou mj. připisovány tyto benefity: zlepšené vnímání kompetencí (Horn and Weiss, 1991), sebeúcty (Barnett et al., 1992), emoční obratnosti (Hanin, 1997), morálního vývoje (Bredemeier and Shields, 1987) aj. (respektování pravidel, soupeřů apod.).

Sport a pohybové aktivity jsou obzvláště u dětí a mládeže jedním z nejefektivnějších nástrojů prevence negativních sociálních jevů, jako jsou kriminalita, alkoholismus či užívání drog (např. Amis, 2000). Jak již bylo zmíněno výše - pohybové aktivity jsou primárním prostředkem v prevenci před civilizačními chorobami, jakými jsou např. obezita, kardiovaskulární onemocnění apod. (např. Cooper, 1986). Dále je pohyb známým antistresovým činitelem (např. Slepičková, 2005; Hátlová et al., 2007).

Sport je př́kladem společenské instituce, ve které jsou zahrnuty činnosti jednotlivců ve styku s ostatními. Proto zákonitosti mezilidského chování, které zde platí, jsou stejné jako v ostatních činnostech. Činnost jednotlivce je většinou ovlivňována chováním lidí kolem něho. Jsou zde pravidla komunikace, zrovna tak sportovní pravidla, na kterých se lidé domluví. Komunikace se netýká pouze sdělujících znalostí, je to také složka podporující a udržující vztahy. Způsob řízení vztahů trenéry s jejich svěřenci má důležitý vliv na sportovní prožitek, další účast ve sportu a způsob vnímání sebe sama (Horn, 1985).

Členové sportovních týmů se rámcově chovají obdobným způsobem jako členové ostatních skupin (pracovní skupiny, rodiny). Potřebují se domluvit, čeho se pokusí dosáhnout, jak nejlépe využít dostupné zdroje (např. schopnosti), chápat své místo v týmu a rozumět sociálním zákonitostem uvnitř týmu. Když děti provozují sport, zvláště kolektivní, musí mít rozdílné role v týmu, každé z nich usiluje o vlastní př́spěvek pro tým. Tyto role jsou určené přijatou strukturou týmu a taktickými požadavky hry, ne nutně formálními pravidly.

Míra otevřenosti či uzavřenosti skupiny určuje rozsah, ve kterém může jedinec doufat ve vštípení sociálních změn. Prestiž jedince je také významná, např. kapitán a talentovaný hráč budou mít pravděpodob- 
ně možnost vlivu na tým, ale nováček pravděpodobně nikoliv (Davis et al., 2004). Jiná je tedy socializace lídra týmu a outsidera týmu, navíc je zde předpoklad, že outsidera to časem přestane bavit.

Sportovní týmy mohou zahrnovat členy různých minorit (rasových, národnostních, náboženských) a společenských tříd (např. v př́padě, že daný sport není příliš finančně náročný). Sport proto mủže napomoci odstranit diskriminační bariéry. Ovšem jak uvádí Pigeassou (2000), na provozování sportovní činnosti, chování a představy mohou mít vliv životní podmínky, kulturní rozdíly, výše př́ijmů, pracovní a rodinné podmínky. Dochází zde tedy ke skrytému druhu sociální diskriminace, rozdílnému vztahu k moci, vědomostem a práci, ukazují se hluboké kulturní rozdíly.

„Vztah mezi sportem a společenskými hodnotami je navzájem závislý, protože společenské hodnoty ovlivnujui druhy provozovaných sportů, způsob jejich organizace a motivaci $k$ účasti ve sportovních aktivitách. Ale i opak je pravdou - sport ovlivňuje hodnoty."(Weiss, 2000, s. 40).

Děti a mládež doslova excelují v individuálních sportech - všechna odvětví gymnastiky, plavání, krasobruslení apod. Úspěchy v týmových sportech přicházejí zpravidla později. Kolektivní sporty vyžadují mj. určitý stupeň sociální zralosti, která není v takové míře nezbytná pro individuální sporty. V souvislosti s dětmi a mládeží je třeba ovšem upozornit na respektování základních zákonitostí ontogeneze adekvátní tréninkové zátěže ke stupni růstu a především vývoji organizmu. To si např. uvědomuje gymnastická federace, která zavedla spodní věkovou hranici pro účast mezi dospělými.

Demonstrování schopností, zvládnutí úkolu, uznání společnosti, vítězství, rychlý pokrok a týmová práce bývají cílem účastníků sportu. První tři cíle však platí pro všechny životní situace, když je důležité něco vykonat na dobré úrovni.

Děti s cílem týmové práce zdůrazňují dobrou práci pro mužstvo oproti dosažení individuálního úspěchu. Je zde spojení se souhlasnými motivy, ale důraz je kladen na pomoc ostatním, nikoli na působení na ně. Cíl týmové práce je více vhodný pro dosažení ve sportu než třeba při školním zkoušení a je samozřejmě důležitější v kolektivních sportech než v individuálních (Lee, 1999).

Weiss (2000) tvrdí, že sport zrcadlí společnost. K tomuto závěru došel po rozboru amerického modelu sportu, který přesně odpovídá americké společnosti - „Zvítězit v konkurenčním boji“, a jistého kmene z Nové Guineye, kde hrají tak, aby bylo dosaženo remízy, což odpovídá napřr. rovné dělbě potravin mezi lidmi. To je naprosto nepřijatelné pro americkou kulturu, kde všichni chtějí jasně znát vítěze. Je to možné dokumentovat zápasy hokejové NHL, kde má dlouhodobou tradici prodloužení utkání, jestliže v normální hrací době skončí nerozhodným výsledkem. Dále např. fotbalová utkání („evropského“, nikoli amerického) v nejvyšší americké soutěži též nesměla nikdy skončit remízou, v případě nerozhodného stavu se konaly samostatné nájezdy. Zde si můžeme povšimnout dalšího podstatného rozdílu, kdy namísto tradičních pokutových kopů se v USA provozovaly samostatné nájezdy (po vzoru hokejových).

Weiss (2000, s. 48-50) uvádí př́klady, jak může jednotlivec dosáhnout společenského přijetí a uznání druhými ve sportu:

a) Být uznán jako člen skupiny - být jako ostatní, rovný mezi rovnými, plnoprávný člen skupiny, základní forma sebepotvrzení. Tento typ je typický pro kolektivní a klubové sporty.

b) Uznání v přidělené roli - touha po uznání je zde specifičtější. Vzory chování v jednotlivých rolích mají rysy, které mohou být již vrozené (doba, pohlaví, prostředí, a možná i společenská třída).

c) Uznání v získané roli - jedná se o schopnost vykonávat přidělenou roli, zároveň však jde i o úspěch, který je dosažen něčím, co nesouvisí s vrozenými vlastnostmi. Toto tvoří základ profesionálního sportu.

d) Uznání ve veřejné roli - získává se na místech, kde se lidé scházejí, aby něco sledovali a poslouchali. Vyhledávají tedy něco, co je př́ímo pozorovatelné, což sport splňuje ideálně.

e) Uznání osobní identity - je založeno na společenském přijetí a potvrzení individuální existence tím, že každý člověk je jiný nebo jedinečný. Hlavní roli zde hraje především individuální sport (lyžování, tenis, golf, kulturistika atd.).

"Sport jako společenská instituce se nemůže izolovat nebo oddělovat od širších společenských událostí. Podstata sportu, jeho organizace, cíle, funkce a struktura vypovídají o celé společnosti. Sport proniká do mnohých stupňủ společnosti a je jejich odrazem." (Weiss, 2000, s. 40). 
Mnoho vrcholových sportovců má problémy s ukončením sportovní kariéry, kterou se někdy snaží co nejvíce prodlužovat, a to třeba i přerušovaně, protože mají velké problémy s následným společenským uplatněním (Kadlčík, 2008). Na specifičtější úrovni totiž následuje přizpůsobení aktérů sportu jako subkultuře.

\section{DISKUZE}

Samotný charakter jednotlivých sportů je natolik odlišný, že lze jen těžko očekávat shodné výstupy pro mimosportovní oblast. Uved’me př́klad: Maratonský běžec, který je reálně schopen absolvovat maximálně 2 maratony za rok (zbytek času vlastně tvoří přípravu na tyto závody), versus lyžařr-slalomářr, který má možnost závodit každý týden po dobu téměř půl roku. Maratonec se s největší pravděpodobností bude snažit dokončit každý maraton. Na druhou stranu slalomáři, zvláště ti nejlepší, velice riskují (typickým př́íkladem byl např. Alberto Tomba) a jezdí stylem „vabank“ - tzn. výhra nebo nic. Ale i mezi samotnými slalomáři panují značné rozdíly, někteří jezdí tzv. na jistotu (z různých důvodů), jiní riskují. Tyto charakteristiky se mohou dokonce značně lišit u jednotlivých závodníků i během jejich kariéry. V tomto naznačeném př́kladu byly uvedeni zástupci individuálních sportů. Při porovnávání individuálních a kolektivních sportovců lze očekávat zřejmě ještě markantnější rozdíly. Chtělo by se až říci, že existuje „mnoho druhů sportü“...

Zdá se, že hodnota „fair play“, zejména na té nejvyšší úrovni, upadá. Jsou o tom časté důkazy. $\mathrm{Na} \mathrm{OH}$ v roce 2006 pozdější vítěz hokejového turnaje Švédsko poslední zápas ve skupině zjevně vypustilo hned ze dvou důvodů: 1 . aby ušetřili síly do dalších zápasů náročného turnaje; 2 . z taktických důvodů - v př́ipadě prohry na ně ve čtvrtfinále čekal relativně slabší soupeř. Co na tom, že jejich počínání švédská veřejnost v internetovém hlasování tvrdě odsoudila. Zachovali se zcela ve smyslu hesla „historie se nebude ptát JAK, ale KDO zvítězil“. Odpůrci by jistě argumentovali tvrzením o př́lišné náročnosti turnaje (mnoho zápasů v krátkém sledu za sebou) a možnosti se takto zachovat pro všechny týmy. Dále např. ve fotbale je známé „filmování“ faulů, o přiznání tečí ani nemluvě. Reálně zde tedy hrozí, že tolerované unfair jednání se během několika let stane zcela přirozenou a uznávanou „normou“, pokud se tak již nestalo. „Zvítězit za každou cenu“ se pomalu stává hlavním mottem vrcholového sportu. O problematice dopingu se snad netřeba ani zmiňovat.

Právě vrcholoví sportovci představují inspiraci - jsou vzory, idoly zejména pro děti a mládež. Symbolizují úspěch, pro značnou část populace jsou spojeni se zábavou, vzrušením a odreagováním...

Nevědecké, nicméně oficiální materiály poměrně často bezmezně věři zázračnému účinku sportu jako socializačního prostředku:

„Každý osmý Švéd je bud' imigrant nebo jejich potomek. Sport tak hraje klíčovou roli v jejich integraci do švédské společnosti a zlepšuje švédské chápání cizích kultur. Již od roku 1981 zde byl speciální program týkající se sportování imigrantů ve Švédsku." (Sport in Sweden, 2005, s. 15).

Ideu švédského sportu lze charakterizovat: „Chceme organizovat sport na všech úrovních, aby to pozitivně rozvíjelo lidi jak fyzicky, duševně, sociálně, tak kulturně." (Sport in Sweden, 2005, s. 12). Jistěže by oponenti mohli namítnout, že tato publikace je „popularizační brožurou“, ale lze uvést další př́íklad, tentokrát z odborné literatury (Davis et al., 2004, s. 397), kde se uvádí:

„Často je prohlašováno, že sport a fyzická aktivita má množství pozitivních efektů: buduje charakter, podporuje týmovou práci a ducha, rozvijí smysl pro čestnost, učí dodržování pravidel a poskytuje možnost vybití přebytečné energie a agresivity společensky přijatelným způsobem. I když nemáme velké množství výzkumu dokládajících tato tvrzení, náš zdravý rozum a zkušenosti nasvědčují, že sport a pohybová aktivita mají socializační účinek. Jinými slovy se účastí socializujeme do některých norem a hodnot naší společnosti."

Účinky sportu mohou být jak pozitivní, tak i negativní. Záleží na úhlu pohledu. Tento pohled se přirozeně bude velmi lišit dle různých kultur, jelikož každá preferuje rozdílné hodnoty. Nicméně ani př́islušníci jednoho státu se patrně neshodnou na jednoznačném závěru ohledně dopadů sportu, jaké hodnoty by měl sport vlastně pěstovat. Lze se domnívat, že by tyto hodnoty do značné míry korespondovaly s politickou orientací. Důraz na individualitu a prosazení se klade u pravicově smýšlejících jedinců - 
v duchu kapitalismu a hesla prosazení se za každou cenu; sociální, týmové a kooperativnější pojetí spíše u levicově orientovaných lidí.

Klasické sportování $\mathrm{v}$ interakci $\mathrm{s}$ dalšími sportovci $\mathrm{v}$ reálném čase a na stejném místě bude mít $\mathrm{v}$ budoucnu možná čím dál tím větší význam. Tato domněnka vychází z faktu nastupující informační společnosti, kdy přrirozeného kontaktu mezi lidmi zřejmě ubývá. V nedaleké budoucnosti bude možné sportovat doma např. na cyklistickém trenažéru a soupeřit $s$ ostatními na platformě internetu, což bude vlastně obdoba již známých veslařských trenažérů.

\section{ZÁVĚR}

Zkoumání lidského chování a jednání je velice nesnadné, zvláště když si uvědomíme, že do hry vlastně vstupuje de facto neomezený počet proměnných. Co lidský jedinec, to odlišná „anamnéza“. Dost často nejsou výzkumné záměry „převoditelné“ $z$ jednoho kulturního prostředí do druhého.

Pojem socializace je sám o sobě tak široký, a mnohdy chápán různými autory natolik odlišně, že vyslovit jednoznačné závěry o tomto procesu je přinejmenším velice obtížné. Jestliže do hry vstoupí ještě fenomén „sport“, který lze chápat, vnímat, postihovat, provozovat i definovat tolika různými způsoby, tak se zdá nemožné nějaké všeobecně platné závěry formulovat. Sport mj. můžeme provozovat v organizované či neorganizované formě; individuální × kolektivní; na různých úrovních - rekreační, výkonnostní nebo vrcholové (což je „kategorie“ sama pro sebe). Na vrcholové úrovni se sportování často stává živobytím, což samo o sobě přináší určitá specifika. $Z$ tohoto stručného výčtu je jistě patrná možná variabilita a odlišnosti. Kromě již výše zmíněných parametrů vstupuje do centra dění významnou měrou osobnost trenéra, kterou lze označit za jednu z klíčových postav procesu socializace sportem, a to především u dětské a mládežnické populace. Samozřejmě bude také záležet na délce „sportovní kariéry“a její intenzitě. Dalším významným činitelem může být míra úspěšnosti jedinců ve sportu, která se může transformovat do dalších oblastí života. Přinejmenším v podobě sebehodnocení, sebedůvěry, sebevědomí apod.

Obecně se věrí, že dětské hry a sportování hrají důležitou roli v socializování dětí, hodnot a mínění společnosti. To se děje proto, že děti přicházejí do styku s pravidly, společenskými hodnotami a ostatními dětmi a potřebují rozvinout schopnosti, vytrvat a radovat se ze sportovních prožitků. Tudíž hry a sport jsou považovány za předběžný vzor společnosti, ve kterém se děti učí důležitá cvičení, která jim prospívají v pozdějším životě. Dle Patrikssona (1994) je evidentní, že pro děti je důležitější společenská struktura a forma sociální interakce než vlastní druh sportovní aktivity.

Avšak názor, že sport buduje charakter, se př́liš neshoduje s kritikou současné struktury soutěžního sportu pro děti, jež vidí důsledky sportovní účasti převážně negativně. Kritiky se opírají o vzrůstající agresivitu, zpomalující se morální vývoj a pro děti nežádoucí sociální klima.

Lze konstatovat, že autoři, kteří se neopírají či necitují konkrétní výzkumná šetření, vnímají úlohu sportu v socializačním kontextu značně pozitivně - zrěejmě z intuitivních pohnutek. Při širším prostudování výzkumů s touto tématikou lze totéž v menší míre říci o výsledcích amerických výzkumů ve srovnání s evropskými závěry. To může být způsobeno značnou rozdílností kultur obou zmíněných civilizací. Nicméně dalším důležitým faktorem může být větší množství provedených výzkumných šetření, a tím i určitý náskok v metodologické oblasti u amerických badatelů.

Patriksson (1994) tvrdí, že sport jakožto společenská instituce této velikosti a významu by měla mít nějaký vliv na socializační proces. Rozšířenost sportu zvláště mezi dětmi a mládeží vede $\mathrm{k}$ závěru, že musí odrážet mnoho běžných norem a hodnot vyzrálé společnosti, a tudíž přispívá k reprodukci příznačných společenských hodnot. Navíc je mládež nejtvárnější skupinou obyvatel.

Bylo by velkou chybou nahlížet na sport jen z pohledu jeho fyzických dopadů, jelikož jsou známy i významné psychické, ale třeba i sociální efekty sportovních, potažmo pohybových aktivit. „...Sport může překonat sociální bariéry a posilnit jednotlivce. Pomáhá redukovat antisociální chování, podporuje celoživotní učení, dává př́ležitosti k zapojení se do života komunity pomocí dobrovolné práce." (Sport in England, 1999; in: Amis, 2000, s. 23).

Pokud tedy budeme sport pojímat $\mathrm{z}$ celospolečenského hlediska, pak dojdeme $\mathrm{k}$ závěru, že je velmi vhodným nástrojem pro vybití „přebytečné lidské energie“ společensky přijatelným způsobem v mezích 
sportovních pravidel. Dále lze zmínit, že mnohé výzkumy ukázaly na menší konzumaci návykových látek (alkohol, drogy) mezi sportovci oproti nesportovcům (např. Slepičková, 2001).

Nepopiratelný je „sdružovací efekt“ sportovních fanoušků. Zejména u dospělých osob se obecně věrí $\mathrm{v}$ „utužovací efekt“ sportu, čehož jsou důkazem různé firemní sportovní akce („team building“, často s nádechem dobrodružna) pořádané pro zaměstnance.

V seniorském věku, kdy dochází k odcizení od společnosti, sport mimo jiné funguje jako prostředek opětovného začlenění do společnosti, což při stárnoucí populaci bude stále aktuálnější.

Z nastíněných skutečností je patrné, že sport sám o sobě nemá automaticky socializační schopnost, jak se domnívají někteří autoři. Na druhou stranu nelze zpochybňovat jeho socializační potenciál, ale tento potenciál nelze zveličovat. V zásadě asi bude socializační potenciál sportu obdobně silný jako u ostatních smysluplných společenských aktivit (hra na hudební nástroj, divadlo apod.).

Ovšem kdybychom sportovní aktivity rozšírili na aktivity pohybové, tak mají de facto nezastupitelnou úlohu. Je možné to shrnout známým rčením „Duo cum faciunt idem, non est idem“ (Když dva dělají totéž, není to totéž). Jde tedy o to, aby se podařilo nalézt a identifikovat ty parametry sportu, které mají pozitivní socializační dopad v co možná největší šírí lidského bytí.

Sport a pohybové aktivity (např. v zaměstnání, při dopravě apod.) se s tendencí zvyšující se hypokineze stávají podstatnějším atributem životního stylu. Jejich pozitivní role nespočívá jen ve „fyzickém“ zdraví, ale i psychickém, které je neméně důležité, a to nejen při aktivním provozování sportu, ale i při jeho pasivní konzumaci - diváctví. Sport totiž má mj. potenciál lidi sdružovat a umožňovat jim společné smysluplné trávení volného času, což se ukazuje zejména v kontextu doby - informační společnosti, kde se mnoho kontaktů mezi lidmi produktivního věku odehrává pouze na bázi informačních a komunikačních technologií - jako velmi podstatná alternativa. Dále jsou sportovní aktivity prospěšné pro navozování či udržování sociálních kontaktů u stále početnější seniorské populace. Mnohé výzkumy na tyto benefity sportovní aktivity seniorské populace jednoznačně ukazují (Ruuskanen and Ruoppila, 1995; McAuley and Blissmer, 2000; McAuley et al., 2005; WHO, 2008).

\section{Literatura}

AMIS, J. (2000). Sport v Anglii. In: P. Slepička, I. Slepičková (Eds.). Sport, stát, společnost. Praha: UK FTVS, s. 23-29.

Australian Sports Commision (1991). Sport for Young Australians: A summary of Market Research Findings. Canberra: Australian Sports Commission.

BANDURA, A. (1977). Social learning theory. New Jersey: Prentice Hall.

BARNEKOW-BERGKVIST, M. (1997a). Physical capacity, physical activity and health - A population based fitness study of adolescents with an 18-year follow-up (dissertations). Umeå: Arbetslivsinstitutes tryckeri.

BARNEKOW-BERGKVIST, M., HEDBERG, G. and JANLERT, et al. (1997b). Prediction of Physical Fitness an Physical Activity Level in Adulthood by Physical Performance and Physical Activity in Adolescence - An 18-year Follow-up Study. In Physical capacity, physical activity and health-A population based fitness study of adolescents with an 18-year follow-up. Umeå: Arbetslivsinstitutes tryckeri.

BARNETT, N. P., SMOLL, F. L. \& SMITH, R. E. (1992). Effects of enhancing coach-athlete relationships on youth sport attrition. The Sport Psychologist, 6, 111-128.

Bílá kniha o sportu. (2008). Praha: MŠMT.

BREDEMEIER, B. J., \& SHIELDS, D. (1987). Moral growth through physical activity: A structural developmental approach. In: D. Gould \& M. R. Weiss (Eds.), Advances in pediatric sport sciences: Behavioral issues (Vol. 2, pp. 143-156). Champaign, IL: Human Kinetics.

COAKLEY, J. (1990). Sport in society (Fourth Edition). St.Louis: Times Mirror/Mosby College, Publ. COAKLEY, J. \& WHITE, A. (1992). Making decisions: Gender and sport participation among British adolescents. Sociology of Sport Journal, 9, 20-35.

COAKLEY, J. (2001). Sport in society: Issues and controversies (Seventh ed.). Boston: McGraw-Hill. 
DAVIS, B., ROSCOE, J., ROSCOE, D. \& BULL, R. (2004). Physical Education and the study of Sport (Fifth Edition). London: Elsevier Mosby.

DOVALIL, J. (2002). Výkon a trénink ve sportu. Praha: Olympia.

Evropská deklarace urbanistických práv (1992). URL: <http://www.veda.cz/findInSection.do?sectionId=1 252\&categoryId=3775> [cit. 2006-8-8].

Evropský manifest o mladých lidech a sportu (1995). Praha: MŠMT.

Evropská charta sportu (1994). Praha: MŠMT.

FLEMR, L. (2009). Prostorové a materiální podmínky pro pohybové aktivity mladších adolescentů ve Středočeském kraji. Disertační práce. Praha: UK FTVS.

GILROY, S. (1999). Whose sport is it anyway? Adults and children's sport. In: M. Lee (Eds.), Coaching Children in Sport. (pp.17-26). London, New York: E \& FN Spon.

GREENDORFER, S.L. \& EWING, M.E. (1981). Race and gender differences in children's socialization into sport. Research Quarterly, 52, 301-310.

GREENDORFER, S.L. (1992). Sport socialization. In: T.S. Horn (Eds.), Advances in sport psychology (pp. 201-218). Champaign: Human Kinetics.

HÁTLOVÁ, B., ŠPƯRKOVÁ, A. \& ŠMÍDOVÁ, J. (2007). Pohyb a mentální zdraví. Česká kinantropologie, 11 (3), 25-30.

HENDRY, L.B. (1992). Sport, Leisure and the Development of Adolescent Lifestyles. Paper presented at the Olympic Scientific Congress, Malaga.

HOGG, M. \& ABRAMS, D. (1988). Social Identifications: A Social Psychology of Intergroup Relations. London: Routlenge.

HORN, T.S. (1985). Coaches' feedback and changes in children's perceptions of their physical competence. Journal of Educational Psychology, 77(2), 174-186.

HORN, T. S., \& WEISS, M. R. (1991). A developmental analysis of children's self-ability judgements in the physical domain. Pediatric Exercise Science, 3, 310-326.

HURRELMAN, K. (1998). Social structure and personality development. Cambridge: Cambridge University Press.

CHOUTKA, M. (1978). Sport a společnost. Praha: Olympia.

CHOUTKA, M., DOVALIL, J. (1991). Sportovní trénink. Praha: Olympia, Karolinum.

JANSA, P. (2002). Názory (postoje) a zájmy adolescentní mládeže o sport, tělesnou výchovu a jiné pohybové aktivity. Česká kinantropologie, 6 (2), 23-39.

JANSA, P., KOCOUREK, J., VOTRUBA, J., aj. (2005). Sport a pohybové aktivity v životě české populace. Praha: UK FTVS.

KRÁLÍK, M. (2001). Sportovní legislativa na prahu třetího tisíciletí. In: P. Tilinger, A. Rychtecký a T. Perič (editoři). Sport v České republice na začátku nového tisíciletí 1. Praha: UK FTVS, s. 467-468.

KADLČÍK, J. (2008). Sportovní kariéra, její ukončení a proces adaptace do postsportovního života bývalých vrcholových sportovců vybraných sportů v ČR. Disertační práce. Praha: UK FTVS.

KELLER, J. (2002). Úvod do sociologie. Praha: Slon.

KOIVULA, N. (2000). Children's gender-typing of physical activities and their parents' stereotyped expectations of feminity and masculinity. Aktuell beteendevetenskaplig idrottsforskning. Svebi:S Årsbok. Pp.103-112.

KREIDL, M. \& HOŠKOVÁ, L. (2008). Měření socioekonomického statusu a zdraví. Pracovní texty Katedry sociologie FF ZČU č. 06/2008. URL: <http://www.kss.zcu.cz/texty.php> [cit. 2008-28-10].

KREMER, J. \& SCULLY, D. (1998). Psychology in Sport. East Sussex: Psychology Press Ltd.

LEE, M. (1999). (Eds.). Coaching Children in Sport. London, New York: E \& FN Spon.

LEWKO, J.H. \& GREENDORFER, S.L. (1988). Family influences in sport socialization of children and adolescents. In SMOLL, F.L., MAGILI, R.A. \& ASH, M.J. (eds.) Children in Sport, 3rd ed., Champaign, IL: Human Kinetics.

McAULEY, E. \& BLISSMER, B. (2000). Self-efficacy determinants and consequences of physical activity. Exercise and sport sciences reviews, 28, 85-88. 
McAULEY, E., ELAVSKY, S., MOTL, R.W., KONOPACK, J.F., HU, L. et al. (2005). Physical activity, selfefficacy, and self-esteem: Longitudinal relationships in older adults, Journals of Gerontology Series B: Psychological Sciences and Social Sciences 60, 268-275.

Modifikovaný návrh směrnic pro sport dětí a mládeže (1998). Praha: ČSTV.

NAKONEČNÝ, M. (2000). Sociální psychologie. Praha: Academia.

PATRIKSSON, G. (1979). Socialisation och involvering i idrott. Göteborg: Acta Universitatis Gothoburgensis.

PATRIKSSON, G. (1994). Sport and physical activity as a socialisation environment (A scientific review). Göteborg: Council of Europe.

PIGEASSOU, C. (2000). Sport a integrace do společnosti - mezi mýty a realitou. In: P. Slepička, I. Slepičková (Eds.). Sport, stát, společnost - dodatek. Praha: UK FTVS, 2000. s. 20-37.

RAUDSEPP, L., \& VIIRA, R. (2000). Socio-cultural correlates of physical activity in adolescents. Pediatric Exercise Science, 12, pp. 51-60.

ROKEACH, M. (1973). The Nature of Human Values. New York: The Free Press.

ROWLEY, S. (1986). The role of the parent in youth sports. In: G. R. Gleeson (Ed.), The Growing Child in Competitive Sport, (pp. 92-99). London: Hoddon and Stoughton.

RUUSKANEN, J.M. \& RUOPPILA, I. (1995). Physical activity and psychological well-being among people aged 65 to 84 years. Age and Ageing, 24, 292-296.

RYCHTECKÝ, A. (Eds.). Monitorování účasti mládeže ve sportu a pohybové aktivitě v České republice. (2006). Praha: UK FTVS.

RYCHTECKÝ, A., aj. (2000). Monitorování účasti ve sportu a pohybové aktivitě v České republice a v evropských zemích. Závěrečná zpráva grantu MŠMT ČR. Praha: UK FTVS.

SAK, P. (2006). Proměny volného času a zaostávání pedagogiky. URL: <http://www.blisty.cz/2006/7/3/ art29205.html> [cit. 2006-2-9].

SEKOT, A. (2003). Socializace sportem - nezastupitelná součást výchovného procesu. Referát prezentován na 11. konferenci ČAPV - Sociální a kulturní souvislosti výchovy a vzdělávání.

SEKOT, A. (2008). Sociologické problémy sportu. Praha: Grada.

SEKOT, A. (2009). Sport a společnost: socializační souvislosti. In: M. Blahutková (editorka). Sport a kvalita života 2009. Brno: FSpS.

SLEPIČKA, P. (1995). Psychology of the Sport Spectator. 270-289. In S.J.H. Biddle (Eds.), European Perspectives on Exercise and Sport Psychology (pp.270-289). Exeter: Human Kinetics.

SLEPIČKA, P. (2000). Sport a česká společnost. In P. Slepička, I. Slepičková (editoři). Sport, stát, společnost. Praha: UK FTVS, s. 9-22.

SLEPIČKA, P., \& SLEPIČKOVÁ, I. (2002). Sport z pohledu české společnosti - II. Česká kinantropologie, $6(2), 7-21$.

SLEPIČKOVÁ, I. (2001). Sport a volný čas adolescentů. Praha: UK FTVS.

SLEPIČKOVÁ, I. (2005). Sport a volný čas. Praha: Karolinum.

Směry státní politiky na léta 2004-2006. URL: <http://www.msmt.cz/Files/TVS/Sport/2003/SMERY_ STATNI_POLITIKY_R.doc > [cit. 2007-5-5].

SMOLL, F. L. \& SMITH, R. E. (2002). Children and Youth in Sport. A Biopsychosocial Perspective. Dubuque, Iowa: Kendall/Hunt Publishing Company.

Sport in Sweden. (2005). Swedish Sports Confederation.

ŠPAČEK, O. (2007). Sport jako statusový symbol. In: I. Slepičková, L. Flemr (editoři). Aktuální otázky sociologie sportu. Praha: UK FTVS, s. 14-19.

TROCHIM, W., DONNELLY, JP. (2007). Research methods knowledge base. 3rd Edition, Atomic Dog. VALJENT, Z. (2004). Tělesná výchova a sport na FEL ČVUT očima studentů. Tělesná výchova a sport mládeže, 70 (7), 44-46.

VALJENT, Z. (2009). Why Does University Study Usually Mean an End to Sport Career? Acta Universitatis Carolinae, Kinanthropologica, 45 (1), 115-129. 
WANKEL, L. \& KREISEL, P.S.J. (1985). Factors underlying the enjoyment of youth sports: sport and age group comparisons. Journal of Sport Psychology, 7, 51-64.

WEISS, M.R. (1987). Self-esteem and achievement in children's sport and physical activity. In: Advances in Paediatric Sports Science: Vol.2 Behavioral issues, (Eds. D. Gould \& M.R. Weiss), Champaign: Human Kinetics.

WEISS, M.R., McAULEY, E., EBBECK, V. \& WIESE, D.M. (1990). Self-esteem and causual attributions for children's physical and social competence in sport. Journal of Sport and Exercise Psychology, 12(1), 21-36.

WEISS, O. (2000). Faktory ovlivňující účast na sportovním dění v Rakousku. In: P. Slepička, I. Slepičková (Eds.). Sport, stát, společnost. Praha: UK FTVS, 2000. s. 251-267.

WHITEHEAD, J. (1988). Why children take part. The ISCiS Journal, 1, 23-31.

WHO (2008). Age-friendly cities: Global ageing and urbanization are successes of humanity. URL: <http:// www.who.int/ageing/age_friendly_cities/en/index.html> [cit. 2007-12-10].

World Manifesto of Physical Education (FIEP, 2000).

Zákon č. 115/2001 Sb., o podpoře sportu, ve znění novely zákona č. 219/2005 Sb.

ZICH, F. \& UNGR, V. (1995). Tělovýchovné a sportovní aktivity mládeže (Výsledky empirického sociologického výzkumu). Zpracováno v rámci grantu MŠMT ČR. Praha: Amasia. 